DOI: $10.14746 /$ pi.2021.13.13

\title{
Lekcje (polskiego) z wielokulturowości. Praca z serią Wojny dorosłych - historie dzieci w szkole podstawowej na wybranych przykładach
}

\author{
Polish lessons on multiculturalism in the L1 \\ classroom. The literature series War of adults - stories \\ of children in the primary school
}

\author{
$\mid$ Karolina Wawer
Uniwersytet Jagielloński
ORCID: 0000-0003-2177-8922
}

\begin{abstract}
The thesis of the article is the issue of omitting cultural and ethnic diversity in L1 educational curricula in Poland. However there is an existing body of children's literature devoted to the matter. In the article the author investigates the contemporary literature for children and young adults, with the focus on migration crisis in Europe. The article comments on the books from the Wojny dorosłych - historie dzieci publishing series. In the part of the text, which is dedicated to didactical practice, the article offers broad descriptions of educational aims and methods, as well as content of lessons with readings: Która to Malala? by Renata Piątkowska and Teraz tu jest nasz dom by Barbara Gawryluk.
\end{abstract}

Key words: Polish L1 classroom, primary school education, multiculturalism, migration crisis in children's literature, culture shock, Malala Yousafzai, war in Ukraine

Streszczenie: Artykuł podejmuje temat wielokulturowości, rzadko obecny na lekcjach języka polskiego w szkole podstawowej. Autorka dokonuje przeglądu i charakterystyki serii wydawniczej Wojny dorosłych - historie dzieci, ze szczególnym uwzględnieniem książek, które podejmują temat kryzysu migracyjnego. W części poświęconej praktyce polonistycznej omówione zostały szczegółowo dwa cykle lekcji zaplanowane i przeprowadzone wokół książek Która to Malala? Renaty Piątkowskiej oraz Teraz tu jest nasz dom Barbary Gawryluk. Opisano konkretne, sprawdzone w praktyce działania dydaktyczne wraz z ich celami i funkcją edukacyjną.

Słowa kluczowe: dydaktyka polonistyczna, wielokulturowość, szok kulturowy, uchodźcy i imigranci w literaturze dziecięcej, Malala Yousafzai, wojna w Ukrainie

Lekcje polskiego są spotkaniem z literaturą i dziełem sztuki, wprawką oratorską i retoryczną, służą doskonaleniu komunikacji językowej i niewerbalnej. Jedną z ważniejszych - według mnie - ról przez nie pełnionych (przy wsparciu zajęć z historii oraz godziny wychowawczej) jest mierzenie się z problemami współczesności, pomoc uczniom w dostrzeżeniu i rozumieniu otaczającej nas rzeczywistości w jej wymiarze społecznym i kulturowym. 
Obecne podstawy programowe (wprowadzone w 2017 roku), zarówno z języka polskiego, jak i historii, nie realizują tej funkcji. Nie zobowiązują, ani też nie zachęcają nauczyciela do zabierania głosu w sprawie kryzysu europejskości, migracji, wielokulturowości, nowego nacjonalizmu i mowy nienawiści. Proponowane w nich treści i lektury wskazują na zwrot ku bezpiecznej tradycji (której się intelektualnie nie kwestionuje) oraz polonocentryzm, przesłaniający szerszą - europejską, światową - perspektywę¹.

Tymczasem trudne zadanie przybliżenia historii rozgrywającej się na naszych oczach, tym trudniejsze, że skierowane do najmłodszego czytelnika, podejmują autorzy w ramach niezwykłej serii wydawniczej Wojny dorosłych - historie dzieci. Celem tego tekstu jest krótka charakterystyka serii oraz przedstawienie propozycji metodycznych poświęconych dwóm wybranym książkom: Która to Malala? Renaty Piątkowskiej oraz Teraz tu jest nasz dom Barbary Gawryluk.

\section{Charakterystyka serii}

Rdzeń serii Wojny dorosłych - historie dzieci stanowią książki opowiadające historię II wojny światowej. Znajdziemy tu teksty przedstawiające realia okupowanej Warszawy i Powstania Warszawskiego (Zaklęcie na W Michała Rusinka, Asiunia i Mój tato szczęściarz Joanny Papuzińskiej, Wojna na Pięknym Brzegu Andrzeja Marka Grabowskiego), kreślące obraz życia w getcie łódzkim, warszawskim, krakowskim (Bezsenność Jutki Doroty Combrzyńskiej-Nogali, Wszystkie moje mamy Renaty Piątkowskiej, Pan Apoteker Katarzyny Ryrych), a także ukazujące różne aspekty wojennej rzeczywistości, m.in. konieczność rozstania z rodziną i niebezpieczeństwo związane z przekraczaniem granicy z Generalnym Gubernatorstwem (Jadzia Izabeli Klebańskiej), przymusowe wysiedlenia Polaków z Wołynia na tzw. Ziemie Odzyskane, relacje polsko-niemieckie u schyłku wojny (Wysiedleni Doroty Combrzyńskiej-Nogali), zesłania na Sybir (Syberyjskie przygody Chmurki tej samej autorki) czy ukrywanie żydowskich dzieci przed Zagładą we Lwowie (Mała wojna Katarzyny Ryrych).

Bohaterami wszystkich opowieści, a często również ich narratorami, są dzieci. Bardzo ważne, że fabuły oparte są na historycznych faktach, zaś protagoniści najczęściej mają swój pierwowzór. Na końcu książki zamieszczone są informacje o przedstawionych w niej osobach i wydarzeniach, fotografie, skany dokumentów, czasem poznajemy również dalsze losy sportretowanych postaci. Zaproponowana przez wydawcę serii formuła wpisuje się w nurt narracji historycznej prowadzonej przez prywatne opowieści i pamięć

\footnotetext{
${ }^{1} \mathrm{~W}$ Podstawie programowej kształcenia ogólnego dla szkoły podstawowej z 2017 roku pierwszy zapis mówi: „Kształcenie ogólne w szkole podstawowej ma na celu wprowadzanie uczniów w świat wartości, w tym ofiarności, współpracy, solidarności, altruizmu, patriotyzmu i szacunku dla tradycji”. Natomiast w Podstawie programowej z 2009 roku znajdziemy następujące zapisy dotyczące sposobów realizacji wymagań z języka polskiego: „Zadania nauczyciela języka polskiego na II etapie edukacyjnym to przede wszystkim: wprowadzanie ucznia w tradycję i sferę wartości narodowych oraz kształtowanie postawy otwartości wobec innych kultur oraz historii: Zadaniem szkoły jest kształtowanie u uczniów następujących postaw: zaangażowania w działania obywatelskie, wrażliwości społecznej, odpowiedzialności, poczucia więzi, tolerancji.
} 
uczestników wydarzeń historycznych, członków wspólnoty kulturowej. Ich świadectwa - wyrażone poprzez fikcję literacką - wpływają na opowieść o historii i współtworzą pamięć o przeszłości tej wspólnoty. I tak dowiadujemy się, że Włodkiem, który pełnił funkcję łącznika i na swoim dziecinnym rowerku rozwoził meldunki i rozkazy w Zaklęciu na $W$, był Włodzimierz Dusiewicz, Zawiszak, harcerz Szarych Szeregów, dziecięcy powstaniec, później reżyser i scenarzysta filmowy, dziś osiemdziesięciodziewięcioletni świadek historii. Kazią z Wysiedlonych jest Kazimiera Mirosławska, z domu Łobodziec, obecnie mieszkanka Jawora na Dolnym Śląsku, a tytułowa Jadzia to mama autorki książki, Izabelli Klebańskiej. Kanwą Syberyjskich przygód Chmurki stały się tragiczne losy Anny Szwykowskiej-Michalskiej, trzyletniej wówczas dziewczynki, która wraz z mamą, babcią i ciociami po wkroczeniu Sowietów do Polski 17 września 1939 roku otrzymała wyrok dwudziestu pięciu lat zesłania do syberyjskiej tajgi. Jej pradziadkowie: Juliusz Stolle i Wilhelm Krajewski byli założycielami i właścicielami huty szkła Niemen, znajdującej się na terenach dzisiejszej Białorusi. Mężczyźni z najbliższej rodziny bohaterki stracili życie z rąk radzieckich jako „wyzyskiwacze ludu pracującego". Wymienione tu książki przybliżające historię II wojny światowej, mimo że oparte na trudnych i bolesnych doświadczeniach, skupiają uwagę również na jasnych stronach życia w warunkach nieludzkich. Ukazują niezwykłą, a bardzo dla czytelnika pokrzepiającą, zdolność dziecka do adaptacji w nieprzyjaznym środowisku.

Znakiem rozpoznawczym serii są te pozycje lekturowe, które powstały w odpowiedzi na bieżące sprawy współczesności i przybliżają najmłodszym czytelnikom problematykę kryzysu uchodźczego. Nie są to jednak, jak można by się spodziewać, książki publicystyczne, „z tezą”, ale wciągające, wartościowe literacko, historie. Skłaniają do rozmowy i refleksji nad sytuacją dzieci doświadczających obecnie wojny w różnych częściach świata i szukających schronienia. Wśród nich umieścić należy Hebanowe serce Renaty Piątkowskiej z ilustracjami Macieja Szymanowicza, graficznie rozbudowaną opowieść o drodze małego Omenki z Libii do Lampedusy - najniebezpieczniejszym szlakiem migracyjnym² przez Morze Śródziemnes. Dojrzałą literacko i artystycznie propozycją jest Kot Karima i obrazki Liliany Bardijewskiej z ilustracjami Anny Sędziwy. Ucieczka z ogarniętego wojną Damaszku, trudy nielegalnej przeprawy przez granice kolejnych państw, pobyt w obozach dla uchodźców, zmaganie się z barierą językową i kulturową

\footnotetext{
${ }^{2}$ Od 2014 do 2020 roku na tej trasie zginęło ponad dwadzieścia tysięcy osób, przez co szlak śródziemnomorski zyskał miano najbardziej niebezpiecznej drogi, którą pokonują globalni uchodźcy. Zob. Dearden K., Sánchez Dionis, M., Black J., Laczko F., 2020, Calculating "deathrates" in the context of migrationjourneys: Focus on the Central Mediterranean, s. 4, https://publications.iom.int/ system/files/pdf/mortality-rates.pdf (dostęp: 14.05.2020).

${ }^{3}$ Choć w książce poświęconej czytelnikowi najmłodszemu (6-8 lat) ta podróż kończy się dobrze, dorosły odbiorca nie może nie pomyśleć o Alanie Kurdim, trzyletnim Syryjczyku, którego ciało zostało wyrzucone na brzeg Morza Egejskiego nieopodal tureckiego kurortu. Utonął on wraz z matką i starszym bratem 2 września 2015 roku podczas próby przepłynięcia Morza Śródziemnego z Turcji na grecką wyspę Kos. Z syryjskiej rodziny ocalał tylko ojciec. Zdjęcie wyrzuconego na brzeg chłopca, opublikowane na okładkach ponad siedemdziesięciu magazynów w Europie, stało się ikoną wyrażającą tragedię uchodźców i migrantów podczas tzw. kryzysu migracyjnego.
} 
po przybyciu do Polski - a więc doświadczenia dla dziecka traumatyzujące - zostały wyrażone przez obrazy zyskujące w narracji szczególną funkcję, a także są wypowiedziane przez pośrednika - kota Bissa - porte parole milczącego bohatera. Książka ta jest szczególnie polecana jako lektura uzupełniająca w szkole podstawowej. Dobrym pomysłem będzie również sięgnięcie wspólnie z uczniami po opowiadanie Rafała Witka, zatytułowane Chłopiec z Lampedusy, utrzymane w konwencji przygodowej, realistycznej fabuły dla młodzieży, w której jedną z głównych ról odgrywa Andżelika, polska imigrantka ekonomiczna. Autor umieszcza bohaterkę w nietypowym dla polskich lektur kontekście, czyniąc z nas współobywateli globalnego świata, odpowiedzialnych za wspólny świat.

Wyróżnikiem serii jest ilustracja artystyczna. Każdą książkę współtworzy wraz z autorem rysownik, nadając jej wyjątkowy estetyczny wymiar i wartość. Z pisarkami i pisarzami współpracują wybitni współcześni ilustratorzy - Joanna Rusinek, Anna Sędziwy, Magdalena Kozieł-Nowak, Maciej Szymanowicz i inni. Ich prace przemawiają do wyobraźni czytelników i mają walor edukacyjny. Mogą być wykorzystane przez nauczyciela podczas omawiania lektury bądź wprowadzenia do niej - jak pokazuje niniejszy tekst. Argumenty przemawiające za wykorzystaniem najnowszej literatury dziecięcej i młodzieżowej w edukacji szkolnej zostaną pogłębione w opisanych poniżej przykładach polonistycznych praktyk.

\section{Która to Malala? O wartości edukacji}

Malala Yousafzai jest współczesną bohaterką, „najodważniejszą dziewczyną na świecie" ${ }^{4}$, aktywistką na rzecz praw dzieci i kobiet, przede wszystkim prawa do edukacji dziewczynek. W 2020 roku ukończyła studia na Uniwersytecie Oxfordzkim. Jest najmłodszą laureatką Pokojowej Nagrody Nobla - w 2014 roku, gdy ją otrzymała, miała siedemnaście lat. Dwa lata wcześniej życie nastolatki z pakistańskiej Doliny Swat zawisło na włosku. „Która to Malala?” - to słowa zamaskowanego napastnika, który wsiadł do szkolnego autobusu, by wykonać wyrok śmierci wydany przez talibów. Postrzelił uczennicę w głowę. Ostatecznie uratowano jej życie w brytyjskim szpitalu, gdzie obudziła się dziesięć dni później.

W jaki sposób nastoletnia dziewczynka mogła „zadrzeć” z fundamentalistami, którzy samozwańczo przejęli władzę w Dolinie Swat? Otwarcie sprzeciwiała się zakazowi edukacji dziewcząt, (która, według talibów, jest sprzeczna z islamem). O zamykaniu szkół i terrorze wprowadzonym przez talibów pisała na blogu pod pseudonimem Gul Makai (Bławatek). Można powiedzieć, że z pomocą ojca, notabene nauczyciela, działała jako opozycjonistka. Dziś wspólnie tworzą Malala Fund - fundację, która wspiera uczennice i edukatorów działających przeciw dyskryminacji kobiet, przede wszystkim w Afganistanie, Indiach, Pakistanie, Syrii, Brazylii, Nigerii. Gdy w Oxfordzie spotkała się z Gretą Thunberg - szwedzką aktywistką

\footnotetext{
${ }^{4}$ Tak podpisał jej zdjęcie na okładce „Newsweek”, (Piątkowska 2015, 56).
} 
klimatyczną - zażartowała, że jest to jedyna przyjaciółka, dla której poszłaby na wagary5. Historia życia Malali, jak i jej działalność społeczna, czynią z niej współczesną bohaterkę, a także wzorzec osobowy dla młodych. Stąd pomysł, by przedstawić polskim uczniom i uczennicom tę postać poprzez lekturę książki Renaty Piątkowskiej z ilustracjami Macieja Szymanowicza. Celem lekcji ${ }^{6}$ było zapoznanie ich z biografią Malali, ale równie ważna była dyskusja o edukacji. Czy prawo do nauki, którego domagała się młoda Pasztunka i za co niemal straciła życie, jest wartością dla jej rówieśników, polskich dwunastolatków? Czy czują, że pełnią podmiotową rolę w swoim procesie edukacji i co zmieniliby w szkole, gdyby mieli większe poczucie sprawstwa? Lekcja rozpoczęła się zatem od anonimowej ankiety z pytaniem Czy lubisz szkołę? Poniżej zestawiono przykładowe odpowiedzi’:

Według mnie w szkole nie tylko się
uczymy, ale także spotykamy się ze
znajomymi. Szkoła to dobry pomysł na
nudę - tam zawsze się coś dzieje. Np.
emocje po sprawdzianie, umawianie się
po szkole.
W miarę lubię chodzić do szkoły jest ona
potrzebnym miejscem. Poznaje się tu
nowych ludzi.
Szkoła jest ok. Spotykam tam znajomych.
Najlepiej się chodzi, jak jest ciepło i
świeci słońce, ponieważ wtedy się
przyjemnie wstaje.

Uważam, że szkoła uczy tak, że uczeń traci chęć do nauki.

Chodzę do szkoły, bo muszę.

Wolałabym zostać w domu.

Szkoła to najgorsze miejsce na świecie

Może być, nie lubię nikogo, a nauczyciele są bardzo mili.

\section{Ilustracja 1. Wyniki ankiety}

Wyraźnie wynika z nich, że szkoła jest dla nastolatków przede wszystkim przestrzenią społeczną, a równie ważne jak zdobywanie wiedzy, praca intelektualna i twórcza, jest bycie w grupie, w związku z czym należałoby się zastanowić, czy szkoła rozwija kompetencje społeczne uczniów. Wstępne rozeznanie wskazało, że opinie na ten temat są podzielone, przeważa jednak nastawienie umiarkowanie negatywne. W przeprowadzonym podczas lekcji zadaniu polegającym na zaproponowaniu reform w klasie i szkolnym sposobie uczenia się, samo włączenie uczniów w sferę planowania przestrzeni szkoły tak, by tym funkcjom służyła, wzbudziło w nich cieplejsze emocje, co zamanifestowało się w ankietach końcowych.

Zadanie wprowadzające bezpośrednio $\mathrm{w}$ temat lekcji zostało zainspirowane ćwiczeniem wizualna biografia, zawartym $\mathrm{w}$ pakiecie edukacyjnym poświęconym antydyskryminacji dla nauczycieli i trenerów (Antydyskryminacja. Pakiet edukacyjny 2005, 72-74). Uczniowie otrzymali zdjęcie Malali oraz pytania pomocnicze, które miały stymulować/ 
porządkować intuicje na temat nieznanej osoby. Propozycja tego ćwiczenia znajduje się poniżej:
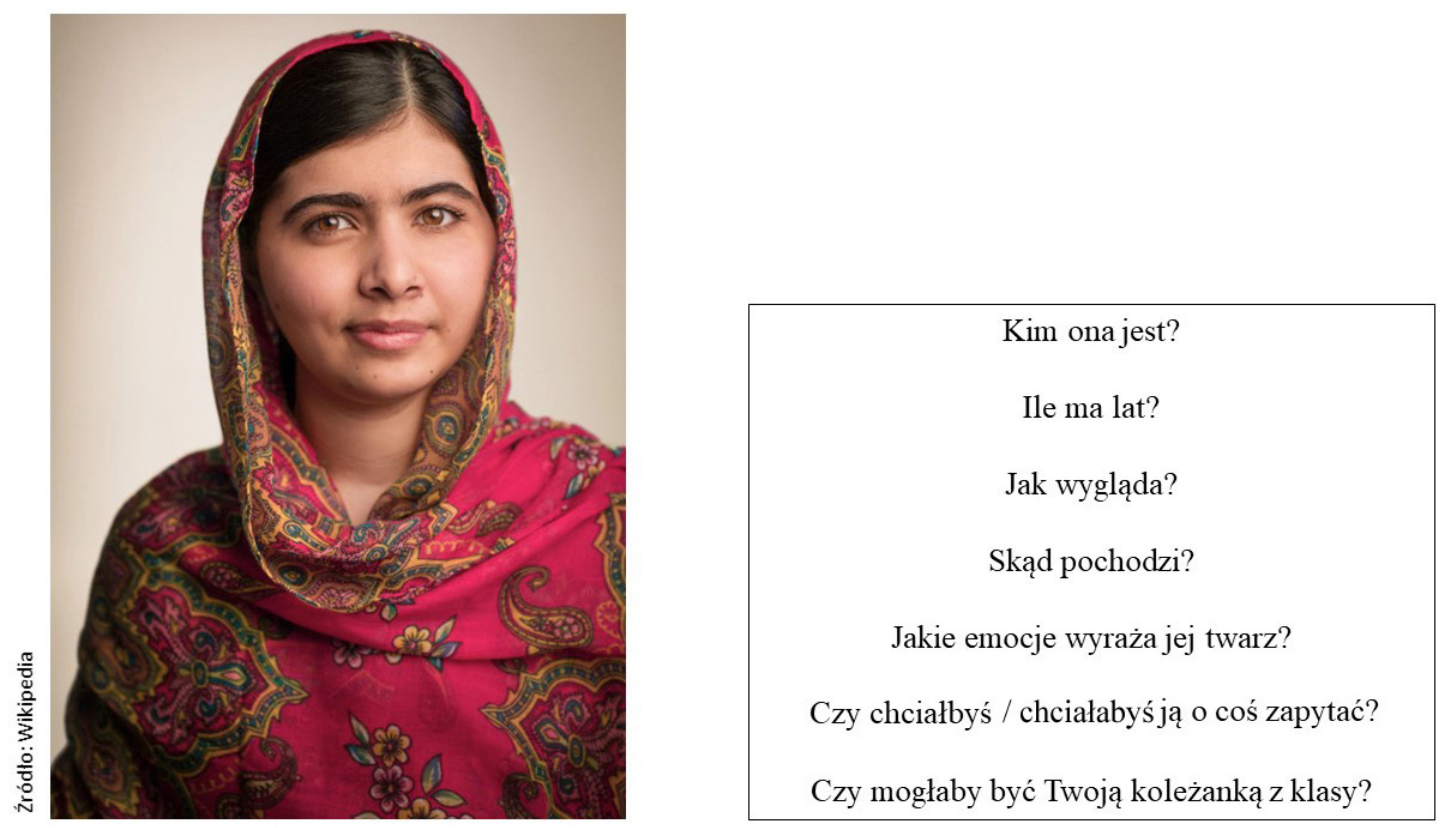

Ilustracja 2. Ćwiczenie wizualna biografia

Zadanie pobudza wyobraźnię, uruchamia proces dedukcji i myślenie narracyjne. Uczniowie zostają wciągnięci w proces rozszyfrowywania tajemnicy, jaką w tym wypadku jest człowiek, jego tożsamość i psychika. Należy być jednak świadomym, że w takim ćwiczeniu zadziała również myślenie za pomocą stereotypów oraz efekt pierwszego wrażenia. Mogą pojawić się uprzedzenia związane z wyglądem, kolorem skóry, ubiorem, co również należy uczynić tematem rozmowy. W przypadku Malali przełamany zostanie stereotyp związany z muzułmankami, postrzeganymi jako zniewolone, pozbawione sprawczości, zajmujące się przede wszystkim tzw. kobiecymi sprawami obowiązkami domowymi i tymi, które wynikają z roli społecznej żony, matki, córki. Uczniowie będą zaciekawieni i zachęceni do tego, by zapoznać się z fragmentem książki o młodej Pakistance. Niektórzy słyszeli o dziewczynce, która dostała Pokojową Nagrodę Nobla, ale nie znają powodów jej przyznania. Wyimek książki (rozdział 3) przybliża działalność Malali i tłumaczy przyczyny ataku terrorystycznego. Rozdział został przystępnie napisany z wykorzystaniem formuły czatu, dzięki czemu można go z powodzeniem odczytać, rozdzielając role między uczniów. Ważne, że zarówno ćwiczenie wykorzystujące wizualną biografię, jak i lektura wybranego fragmentu książki Renaty Piątkowskiej, mają miejsce w kręgu. Takie usadowienie uczniów sprzyja rozmowie, dzieleniu się refleksjami z grupą, partnerskiej relacji.

Uczniowie po odczytaniu i wysłuchaniu rozdziału książki chętnie podjęli dyskusję. Skupili się na ryzyku, jakie niosła bohaterska postawa Malali. Formułowali następujące pytania: Zachowanie Malali było nierozsadne. Dlaczego tata Malali pozwolit jej tak ryzykować? Czy narażanie życia było konieczne? Zastanawiali się również nad dystrybucją informacji 
w zglobalizowanym świecie i logiką pamięci o ważnych postaciach i zdarzeniach w różnych społeczeństwach: Dlaczego mówi się i pamięta tylko o niektórych odważnych osobach? Każdego dnia wiele osób wykazuje się odwaga, ginie w imię dobra wspólnego, a nie jest o nich głośno. Dlaczego pamiętamy tylko o wybranych? Padały również głosy solidaryzujące się z bohaterką opowieści, zainspirowane jej historią: Dlaczego musi się wydarzyć jakaś tragedia, żeby ludzie zaczęli dostrzegać pewne problemy? Dlaczego prawa dzieci (np. prawo do swobodnej wypowiedzi) często sq łamane?

Gdy udało się zdobyć zaufanie uczniów i wywołać ich zainteresowanie, prowadzące lekcję studentki zaproponowały uczniom udział w eksperymencie. Każdy z uczniów otrzymał ponumerowany pasek papieru z wymienionym na nim prawem dziecka. Następnie wybrane losowo numery zostały wyczytane i wyproszone z kręgu. Uczestnicy ćwiczenia zastanawiali się nad tym, czy wszystkie prawa są zasadne, czy powinny obejmować dzieci bez względu na miejsce pochodzenia i zamieszkanie oraz czy są przestrzegane w naszym kraju. Rozmowa ta pozwoliła na przypomnienie praw dziecka lub zapoznanie się z nimi, uświadomienie ich wagi oraz znaczenia dla każdego ucznia. Poniższa ilustracja przedstawia zestawienie praw dziecka, z wyróżnieniem prawa do nauki, stanowiącego przedmiot lekcji:

Czy któreś z tych praw jest niepotrzebne? [Konwencja o prawach dziecka]

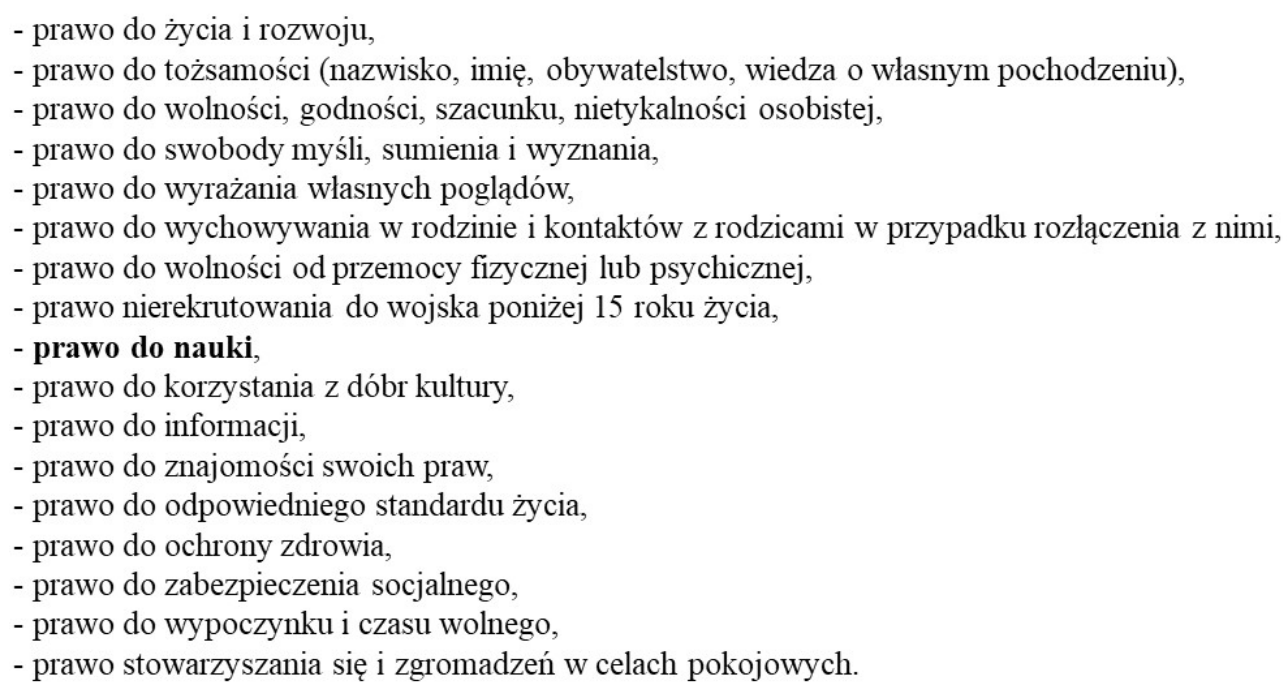

Ilustracja 3. Lista praw dziecka

Kolejna lekcja miała posłużyć przetworzeniu informacji, z którymi uczniowie się zetknęli. Zaplanowano pracę w grupach, polegającą na napisaniu listu otwartego ${ }^{8}$. Tematyka listu była zróżnicowana: uczniowie mieli wyrazić własną opinię o działaniach Malali lub zaproponować program reform szkoły zgodnie z własnymi potrzebami: 


\section{LIST OTWARTY do Ministra Edukacji Narodowej z własnymi pomysłami reform}

zarówno programu, jak i przestrzeni szkolnej. (Pytania pomocnicze: Co sprawiłoby, że do szkoły chodzilibyście z większą ochotą? Czego chcielibyście się uczyć najbardziej, a czego teraz nie obejmuje program? Czy jest jakieś miejsce, które chcielibyście mieć we własnej szkole? Jak powinna wyglądać idealna klasa?)

\section{LIST OTWARTY do Sekretarza ONZ w sprawie Malali Yousafzai}

Uczniowie mogą wyrazić swoje zdanie o pakistańskiej dziewczynce, zgadzając się z nią lub nie. (Pytania pomocnicze: Czy uważacie, że Malala postąpiła słusznie? Jak zachowalibyście się na jej miejscu? Czy jej postępowanie może być przykładem dla innych? Czy myślicie, że dzieci powinny walczyć o swoje prawa?)

\section{Ilustracja 4. Polecenia do pracy grupowej}

Powstały wypowiedzi, które wyrażały uznanie dla działań Malali podejmowanych w obronie prawa do edukacji, przy jednoczesnej niezgodzie (lub braku zrozumienia) na narażenie się jednostki na niebezpieczeństwo na rzecz ideałów. Uczniowie, co zrozumiałe, przykładali przeżycia Malali do znanych sobie warunków bytowych i systemu wartości. Ich reakcje wskazywały na potrzebę uczenia wielokulturowego, aktualizowania wiedzy o sposobach życia osób spoza europejskiego kręgu cywilizacyjnego i odnoszenia się do niej, by kształtować umiejętność zrozumienia (dostrzeżenia różnic, ale i podobieństw w zachowaniu) np. człowieka w sytuacji granicznej, utraty wolności, praw, godności itp. Poniżej zamieszczam przykład uczniowskiego tekstu:

Uważamy, że Malala posiadała wielką odwagę, ponieważ mówiła, co myśli, wiedząc o konsekwencjach jej zachowania. Szanujemy ją ze względu na to, co zrobiła dla wszystkich dziewczyn żyjących w Pakistanie. Dała im możliwość edukacji i pokazała, że można się przeciwstawić, jeśli nasze zdanie jest inne. Jednakże jej zachowanie było bardzo ryzykowne i nieodpowiedzialne. Mogła zginąć, przy tym narażając swoją rodzinę na podobny los.

Sądzimy, że prawo do edukacji jest bardzo ważne, ponieważ każdy z nas powinien mieć możliwość do nauki, rozwijania swoich zainteresowań, czy zdobycia wiedzy potrzebnej do wykonywania zawodu. Należy pamiętać, iż wielu ludzi poniosło śmierć, walcząc o swoje prawa9

W grupach, które pracowały nad propozycjami zmian w szkolnictwie, uczniowie podeszli do zadania z wielkim entuzjazmem. Podczas spontanicznej dyskusji zapomniano o retorycznej formie listu, ale warto spojrzeć na zapisane postulaty:

Profesjonalne wyposażenie sal lekcyjnych. Wymiarowa sala gimnastyczna. Możliwość rozszerzenia wybranych przedmiotów. Nauka ekonomii. Nauka przez wyjścia edukacyjne. Lekcje BHP. Nauka praw człowieka. Zwiększenie dni wolnych z 8 do 
12 (w trakcie roku szkolnego). Zwiększenie długości przerw. Sklepik szkolny oraz automat. Lekcje samoobrony.

Można w nich dostrzec uczniowską potrzebę większej niezależności i samorządności w ramach instytucji, jaką jest szkoła. Wolny wybór przedmiotów, uwzględniający zainteresowania uczniów, również te z dziedziny praxis, czy poszerzenie systemu klasowo-lekcyjnego o alternatywne rozwiązania (wycieczki, wyjazdy, nauka w terenie itp.) wskazują na niedostosowanie szkoły do potrzeb i możliwości współczesności, w której indywidualizm zyskał na znaczeniu. Bolączkę dotyczącą naszego (i nie tylko naszego) systemu edukacji słusznie wyraził Dale Jones, dyrektor jednej z amerykańskich szkół publicznych:

Niestety, większość uczniów odbiera szkołe jako coś, co im się przydarza, a nie miejsce, w którym odgrywają znaczącą rolę. Oczywiście dostają zadania do wykonania i piszą sprawdziany, ale niezmiernie rzadko mają cokolwiek do powiedzenia odnośnie treści zadań bądź najlepszego sposobu, w jaki mogą wykazać się wiedzą. (...) Dzieci posiadają przede wszystkim fundamentalną potrzebę krytycznego zaangażowania się we własną edukację (Nelsen, Lott, Glenn 2020, 12-13).

Aktywność uczniów podczas tego zadania pokazała, że współuczestniczenie w organizacji procesu uczenia się (wzięcie odpowiedzialności za ten proces) działa na ucznia motywująco. Jak ważne było to ćwiczenie, świadczy refleksja uczniów na zakończenie zajęć. Studentki przygotowujące się do roli nauczyciela powtórzyły anonimową ankietę z początku lekcji. Oto odpowiedzi uczniów na ponownie postawione pytanie: Czy lubisz szkołę? Czy coś się zmieniło w Twoim postrzeganiu szkoły po dzisiejszych zajęciach?

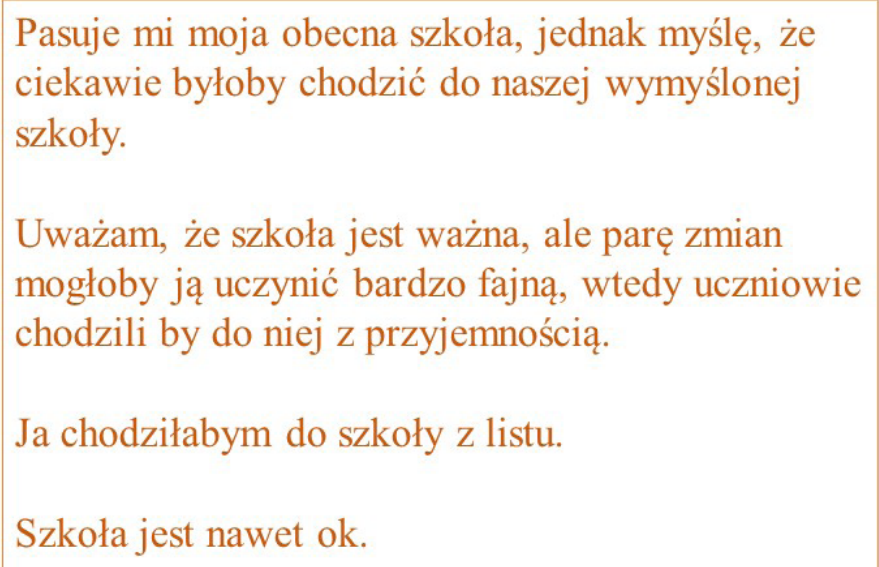

Ja chodziłabym do szkoły z listu.

Szkoła jest nawet ok.

NIE, może.

Wolę siedzieć w domu.

\section{Ilustracja 5. Wyniki ponownej ankiety}

Historia Malali Yousafzai opisana przez Renatę Piątkowską rzuca nowe światło na ważkie problemy polskiej szkoły i naszych uczniów - oczywiście jeśli tylko na taką refleksję pozwolimy na lekcji. Lektura tej książki pozwoliła na namysł nad prawami, które wydają się oczywiste i są w naszych realiach społecznych codziennością (dostęp do wiedzy, możliwość uczenia się), na 
rozważenie osobistej odpowiedzialności za własny proces nauczania, ale także na przemyślenie wpływu uczniów na sposób funkcjonowania obecnej szkoły.

\section{Teraz tu jest nasz dom. Wojna, która jest blisko}

Według szacunków Organizacji Narodów Zjednoczonych ponad 272 miliony ludzi żyjących obecnie na świecie ${ }^{10}$ nie przebywa $\mathrm{w}$ kraju swego pochodzenia (z czego około 10\%, czyli 27 milionów to uchodźcy). Mieszkają oni w zaledwie dwudziestu krajach świata (dane na 2019 rok) ${ }^{11}$. W Polsce w 2020 mieszkało nieco ponad 440 tysięcy osób będących cudzoziemcami ${ }^{12}$, z czego najwięcej osób otrzymujących ochronę (np. status uchodźcy) w naszym kraju ma obywatelstwo rosyjskie i ukraińskie. Książka Barbary Gawryluk z ilustracjami Macieja Szymanowicza jest ważnym głosem w sprawie edukacji wielokulturowej i tolerancji wobec inności; podejmuje temat migracji naszych najbliższych sąsiadów - obywateli Ukrainy. Coraz częściej słyszymy język ukraiński lub rosyjski w przestrzeni publicznej; nową koleżanką/nowym kolegą w klasie naszych dzieci zostaje uczennica/uczeń z Ukrainy. Lektura Teraz tu jest nasz dom oswaja ucznia z imigrantami z Ukrainy oraz przybliża ich problemy, osadzone w kontekście społeczno-kulturowym, zaś w zaprezentowanej tu koncepcji lekcji - skłania do refleksji nad rolą obcego i gospodarza w swoim kraju. Pozwala również na rozmowę o wartościach - życzliwości, szacunku, ciekawości i akceptacji dla inności.

Motywem przewodnim, wokół którego zorganizowano działania lekcyjne, jest zjawisko szoku kulturowego. Proponuję uczniom namysł nad oswojonym pojęciem w taki sposób, by stało się ono interpretacyjnym wytrychem, dzięki któremu uda się zrozumieć punkt widzenia i postępowanie bohaterów. Znajomość objawów szoku kulturowego pozwoli również przygotować zestaw psychologicznych narzędzi do samopomocy, jeśli sami znajdziemy się w podobnej sytuacji - w roli emigranta. Stąd cele lekcji zostały określone w następujący sposób:

Cele lekcji dla ucznia:

- zastanowisz się, jak to jest być obcym w innym kraju,

- poznasz zjawisko szoku kulturowego i dowiesz się, jak mu przeciwdziałać,

- zapoznasz się z książką Barbary Gawryluk Teraz tu jest nasz dom.

Dlaczego ten temat jest ważny?

- możesz znaleźć się kiedyś w takiej sytuacji - będziesz umiała/umiał zareagować

i pomóc sobie,

- ponieważ wokół Ciebie znajdują się osoby w takiej sytuacji (przede wszystkim narodowości ukraińskiej), będziesz umiał/a im pomóc.

${ }^{10} \mathrm{~W} 1990$ roku były to 153 miliony, w ciągu 29 lat liczba ta wzrosła o 119 milionów, za: International Migration Report 2019, 2019, Nowy Jork, s. iv (https://www.un.org/en/development/desa/ population/migration/publications/migrationreport/docs/InternationalMigration2019 Report.pdf (dostęp: 17.03.2021).

${ }^{11}$ Tamże.

${ }^{12}$ Dane statystyczne pochodzą z Urzędu do Spraw Cudzoziemców: https://migracje.gov.pl/statystyki/zakres/polska/typ/dokumenty/widok/wykresy/rok/2020/ (dostęp: 12.05.2020). 
Szok kulturowy to naturalne zjawisko psychologiczne, dotykające każdego podróżnego, który przyjemną rolę turysty zamienia na nieco trudniejszą rolę mieszkańca w obcym kraju. Badania nad tym aspektem migracji koncentrowały się na migracji dobrowolnej (powodowanej np. nauką lub pracą w innym kraju), natomiast w przypadku bohaterów książki Teraz tu jest nasz dom, jak i w sytuacji wszystkich uchodźców - jest to zmiana pobytu motywowana koniecznością, której często towarzyszy trauma. Poniżej przywołuję definicję, która może być pomocna na etapie przygotowania do lekcji:

Szok kulturowy to naturalna reakcja człowieka, który decyduje się na życie w nowym otoczeniu kulturowym. Jest to rodzaj psychologicznej lub emocjonalnej dezorientacji spowodowanej permanentnym stresem wywołanym serią niezrozumiałych i denerwujących sytuacji. Jako że nie przeżywało się ich wcześniej, brakuje jakiegokolwiek punktu odniesienia, wynikającego z dotychczasowych doświadczeń. Im większy dystans kulturowy pomiędzy dwoma krajami, tym na ogół większy szok kulturowy. Na szok kulturowy narażeni są imigranci, uchodźcy, studenci i naukowcy oraz ekspatrianci delegowani do pracy w zagranicznych oddziałach przedsiębiorstwa (Simpson 2014, 567-568).

Zbadanie i zrozumienie zjawiska szoku kulturowego miało być czynnikiem motywującym do udziału w lekcji, a zarazem mobilizującym do przeczytania książki. Szczególny nacisk położono na działania wstępne, mające za zadanie aktywnie i twórczo wprowadzić uczniów w lekturę. Po zapoznaniu uczniów z tematem i celami lekcji widniejącymi na tablicy, prowadząca odczytała następujący fragment futurystycznego opowiadania ${ }^{13}$ :

Jest rok 2025. Mimo apeli naukowców i rekomendacji Szczytu Klimatycznego ONZ państwa świata nie ograniczyły emisji dwutlenku węgla z paliw kopalnych i globalne ocieplenie wymknęło się spod kontroli. Zatonęła Floryda, liczne z wysp Oceanii, Holandia znajduje się częściowo pod wodą - to jedynie kwestia czasu, aż zniknie z mapy Europy.

Polska odczuwa dotkliwy kryzys ze względu na nikłe zasoby wody pitnej. Nikt z obywateli nie ma dostępu do wody bieżącej, jest ona racjonowana. Destabilizacja sytuacji polityczno-ekonomicznej doprowadziła do tego, że o władzę w kraju toczą walkę bojówki. To one przejmują kontrolę nad wodą. Jest coraz niebezpieczniej. Twoja rodzina podejmuje dramatyczną decyzję o ucieczce z Polski.

Osiedlacie się w jednym z państw, w których sytuacja jest wciąż stabilna. Nie znacie dobrze języka, a musicie starać się o pozwolenie na stały pobyt. Musicie zmierzyć się z niewypowiedzianą, ale odczuwaną przez Was niechęcią - nie jesteście tu mile widziani. Wasza obecność - choć zbawienna dla Waszego życia i bezpieczeństwa - oznacza zagrożenie dla kurczących się zasobów obywateli tego kraju.

Zadanie słuchających polegało na wczuciu się w sytuację zarysowaną w opowieści i udzielenie odpowiedzi na dwa pytania: Co czujesz? Co robisz? Z przeglądu propozycji wynikło, że opisane realia wzbudzają podobne reakcje emocjonalne, a powszechnie wskazane uczucie lęku, przybierające różne natężenie (niepewność, niepokój, strach, przerażenie) może wywoływać

${ }^{13}$ Lekcję przeprowadziłam w klasie na podstawie autorskiego konspektu w klasie 7 SP nr 16 w Krakowie, we wrześniu 2019 r. Fragment opowiadania przygotowany na potrzeby lekcji. Konspekt można pobrać na stronie Wydawnictwa Literatura: https://www.wydawnictwoliteratura.pl/do-pobrania/scenariusze-zajec/teraz-tu-jest-nasz-dom/teraz-tu-jest-nasz-dom-1 (dostęp:9.03.2021). 
uczucie złości, gniewu, agresji. Pytanie o podjęcie działania w reakcji na wskazaną sytuację pokazuje wykluczające się możliwości - próbę pokojowego dostosowania się, rezygnację (ucieczkę) lub wrogie przejęcie zasobów (rewolucję). Na poniższej ilustracji przedstawiam odpowiedzi uczniów.

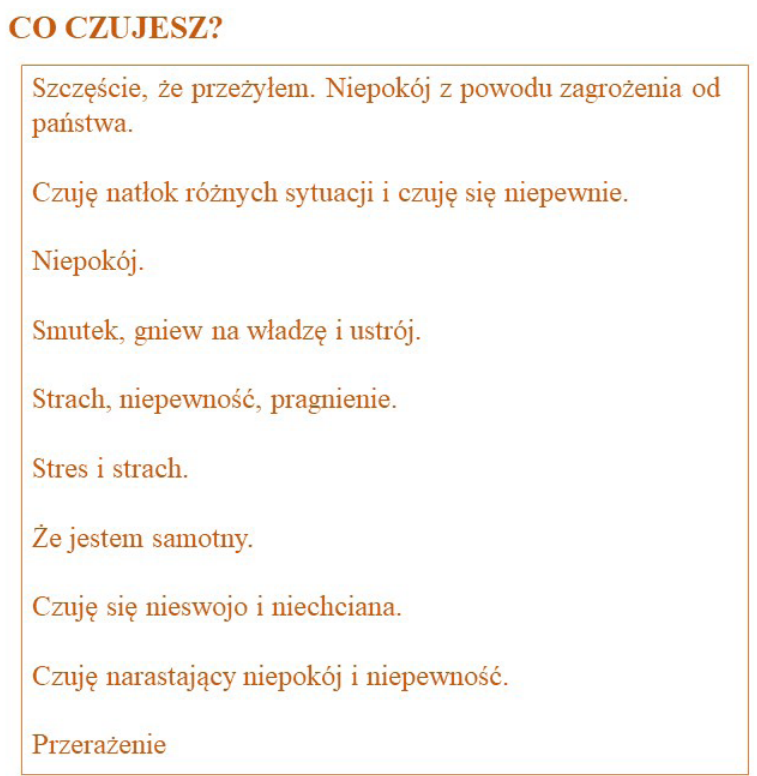

\section{CO ROBISZ?}

Uczę się języka, staram się dostosować.
Staram się przyzwyczaić.
Biorę wszystkiego minimalnie, żeby pokazać, że
dużo mi nie potrzeba.
Staram się z kimś poznać, najlepiej, aby znał taki
język, co ja.
Staram się dogadać z ludźmi.
Próbuję poznać nowe społeczeństwo.
Rozpoczynam rewolucję.
Uciekam do innego państwa.
Zwołuję tajne obrady osób z mojego kraju.

\section{Ilustracja 6. Odpowiedzi uczniów}

Kontynuacją powyższego ćwiczenia wspomagającego empatię była rozbudowująca je wprawka pisarska, polegająca na czytaniu i interpretacji ilustracji Macieja Szymanowicza z omawianej książki. Uczniowie pisali własne fragmenty opowiadania, zainspirowane apokaliptycznym rysunkiem. Dopiero po wykonaniu ćwiczenia otrzymywali informację o wydarzeniach, które stały się kanwą dla ilustracji.

\section{CZYTANIE ILUSTRACJI \\ CO WIDZISZ? OPISZ KRAJOBRAZ. \\ GDZIE I KIEDY TO SIĘ DZIEJE?}

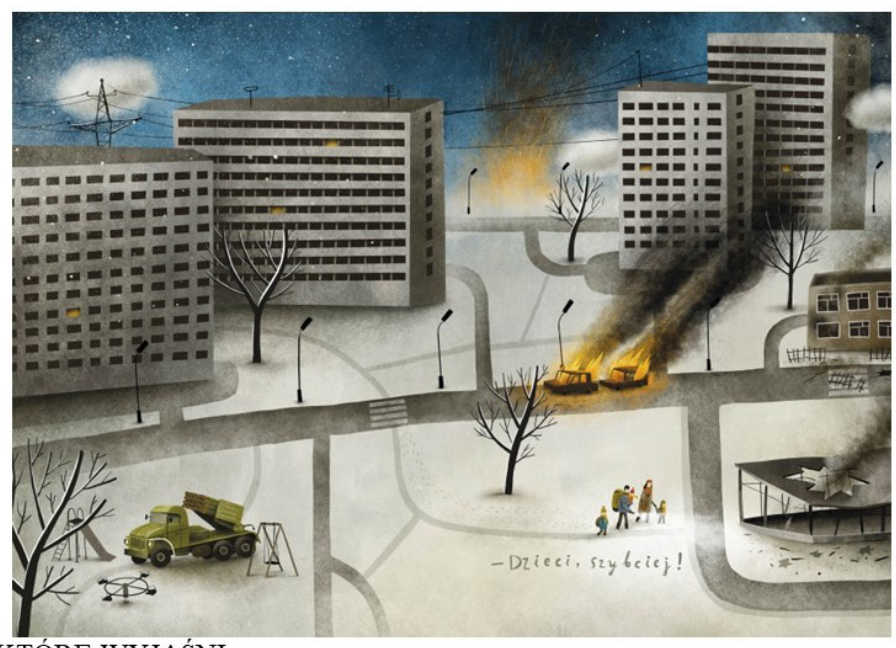

NAPISZ FRAGMENT OPOWIADANIA, KTÓRE WYJAŚNI SYTUACJE PRZEDSTAWIONA NA RYSUNKU.

Ilustracja: Maciej Szymanowicz UWZGLĘDNIJ UCZUCIA I PRZEŻYCIA POSTACI.

\section{Ilustracja 7. Czytanie ilustracji}

Większość uczniów uznała sytuację przedstawioną za krajobraz końca świata, rezultat katastrofy ekologicznej, następstwo wybuchu wulkanu 
lub bomby. Piszący sytuowali te wydarzenia w przyszłości. Nieliczni pisali o wojnie, odnosząc się do II wojny światowej. Dlatego usytuowanie ilustracji w teraźniejszości i powiązanie jej z wojną na Ukrainie, wywołało emocje i ciekawość oraz motywowało do dalszego zaangażowania w działania lekcyjne.

Kolejne ogniwo lekcji poświęcone było lekturze i analizie fragmentów tekstu opowiadania z wykorzystaniem zamieszczonych poniżej objawów szoku kulturowego (za: Grzymała-Moszczyńska 2014, 53-54):

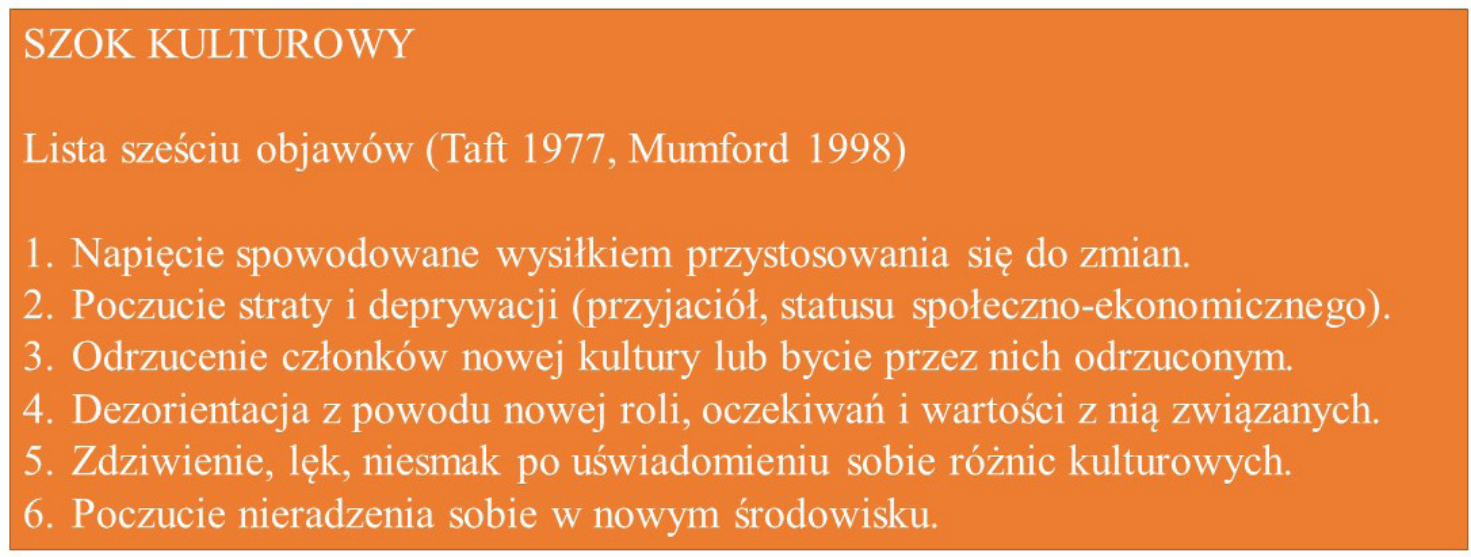

\section{Ilustracja 8. Objawy szoku kulturowego}

Warto przyjrzeć się emocjom i zachowaniu bohaterów książki w kontekście wskazanych wyznaczników szoku kulturowego. Najsilniejszym uczuciem, jakie im towarzyszy jest poczucie straty, przejawiające się na różne sposoby. Romek, najstarszy z rodzeństwa, tęskni za babcią i dziadkiem, którzy zostali w Doniecku. Relacja z dziadkami, czas spędzony wspólnie podczas pysznych obiadów, słuchanie babcinych opowieści, są stale obecne we wspomnieniach, a zarazem stanowią bolesny znak utraty wynikającej z konieczności ucieczki przed wojną i przeprowadzki do Polski. Poczucie straty dotychczasowego życia, choć niewysłowione wprost, obecne jest również w dziecięcej tęsknocie młodszego z braci, sześcioletniego Mikołaja:

Mikołaj przewracał się z boku na bok.

- Tato?

- Tak, synku? Czemu nie śpisz?

- Bo ja ciągle myślę.

- O czym myślisz?

- Kto teraz jeździ na moim rowerku w Doniecku? (Gawryluk 2016, 39).

Rodzice Romka, Mikołaja i Natalii muszą mierzyć się z koniecznością rozpoczęcia wszystkiego na nowo - ich mieszkanie w Doniecku, zniszczone po wybuchu pocisku rakietowego, zostało przejęte przez żołnierzy. „Teraz już naprawdę nie mamy do czego wracać" (Gawryluk 2016, 40) - tak ojciec kwituje to zdarzenie, będące prawdopodobnie przyczynkiem do ostatecznego pożegnania się ze znanym sobie światem. Dla rodziców rekompensatą towarzyszących im trudnych emocji jest świadomość, że dzieci są bezpieczne 
i mogą spokojnie się rozwijać w nowym otoczeniu. Strata, której doznali, ma ścisły związek z wydarzeniami na Ukrainie, spowodowanymi wojną:

Wkrótce tata stracił pracę. Przestał jeździć w delegację, miał dużo wolnego czasu. Rodzice byli niespokojni i smutni, a do słów, które wieczorami docierały do naszego pokoju z kuchni, doszły jeszcze „bieda”, „pieniądze”, „bezpieczeństwo”. I to ciągle powracające: „WOJNA” (Gawryluk 2016, 7).

Przeżycie alarmu bombowego w piwnicy, widok czołgów, eksplozji i zrujnowanej po bombardowaniu dzielnicy, wreszcie ewakuacja pod osłoną wojskowego kordonu - wszystko to stało się udziałem również najmłodszych. Stąd w przypadku rodziny Baranowskich można mówić nie tylko o szoku kulturowym, ale także o stresie pourazowym. Najsilniej uwidacznia się on w zachowaniu Mikołaja, który w szkole przestaje komunikować się z rówieśnikami oraz nauczycielami, mimo że rozumie język polski. Znaczące zdanie, jakie wypowiada chłopiec dwukrotnie, na początku i w zakończeniu książki („A w Doniecku jest wojna” - Gawryluk 2016, 3; 43) stanowi wyraz traumy, ale zarazem zaczątek opowieści, dzięki której tę traumę będzie można przepracować. Inną reakcją na utratę może być niepogodzenie się z nią i bunt. Tak dzieje się w wypadku Weroniki, nastoletniej kuzynki bohatera, która deklaruje chęć powrotu na Ukrainę:

Z Weroniką często siedzieliśmy razem $\mathrm{w}$ autobusie szkolnym, opowiadaliśmy sobie historie z Ukrainy z naszych wakacji na Krymie. Weronika o wiele częściej kontaktowała się z dziadkami, wiedziała, że mają kłopoty ze zdobyciem jedzenia, że ciągle brakuje wody.

- Ta cholerna wojna - powtarzała. - Jak się tylko skończy, wracam do domu.

- Ale przecież nie możesz sama wracać - sprowadzałem ją na ziemię. - Twoja mama mówi, że będziesz chodzić do szkoły w Warszawie.

- Trochę pochodzę, ale jak tylko babcia i dziadek dadzą znać, że jest bezpiecznie, to wracam. Ucieknę z domu najwyżej. To znaczy nie wiem, z jakiego domu, bo ciągle nie znamy w Warszawie adresu. A w Doniecku domu nie ma, same gruzy (Gawryluk 2016, 34).

Powyższy fragment przedstawia sytuację braku stabilizacji, w jakiej znajdują się młodzi uchodźcy. Poczucie zawieszenia, tymczasowości i niepewności co do przyszłości, nawet tej najbliższej, życie na walizkach z pewnością wpływają na problemy z odnalezieniem się w nowym środowisku. Frustracja, spowodowana dyskomfortem długotrwałego przebywania w ośrodku dla uchodźców, wpisana jest w narrację snutą przez Romka:

W tym ośrodku nie było źle, ale z każdym tygodniem coraz bardziej denerwował mnie brak własnego kąta. Pokój był ciasny, telewizję w świetlicy oglądali przeważnie dorośli i ciągle szukali wiadomości z Ukrainy. Tata się wtedy denerwował i wysyłał mnie do pokoju. A przecież widziałem, że nawet w polskiej telewizji pokazywali ruiny domów, czołgi na ulicach i płaczących ludzi (Gawryluk 2016, 26).

Jeszcze boleśniejsze okazuje się odrzucenie przez rówieśników w nowej szkole. Zarówno Mikołaj, jak i Roman doświadczają bycia obcymi. Mikołaj nie odzywa się, a dzieci z zerówki pozostawiają go samemu sobie, na uboczu. 
Nic dziwnego, że czuje się izolowany i samotny. Roman natomiast staje się obiektem niewybrednych uwag i kpin. Takie nastawienie ma wobec chłopca dwóch napastników, nie cała klasa, jednak to wystarczy, by uniemożliwić proces adaptacji w nowym środowisku. Roman jako najstarszy z rodzeństwa ma poczucie, że z problemami - swoimi i młodszego brata - musi poradzić sobie sam. Obiera konfrontację jako strategię obrony. Wymaga ona mobilizacji i odwagi, ale w tym przypadku jest skuteczna i wystarczająca. Sprzeciwia się wykluczeniu ze względu na swoje pochodzenie:

- Nie jestem Ruski. Jeśli już, to Ukrainiec. Ale twój mały mózg zdaje się nie jest w stanie pojąć tej różnicy? A rozumiesz, co do ciebie mówię? (...) Ano właśnie. Jak rozumiesz, to znaczy, że mój polski nie jest taki beznadziejny. To słuchaj dalej. Niedawno widziałem czołgi, rakiety i żołnierzy z karabinami. Uciekaliśmy w nocy, między płonącymi domami. Wtedy się bałem. Dlatego was się wcale nie boję. Boję się wojny, strzałów i wybuchów. Wy nie jesteście groźni, tylko głupi. Durni! I wcale mi na was nie zależy (Gawryluk 2016, 44).

Na szczęście spotyka się ze wsparciem ze strony innych chłopców ze swojej klasy, a swoim publicznym wystąpieniem uświadamia kolegom rolę odwagi w obliczu zagrożenia wojną. Może też zaprezentować swoje bramkarskie umiejętności, gdy zostaje zaproszony do gry w piłkę.

Książka Barbary Gawryluk ma krzepiący wydźwięk; przekonuje czytelników o możliwości poradzenia sobie z przeciwnościami losu oraz oswojenia trudnych emocji, wynikających ze stresu pourazowego czy szoku kulturowego. Jak przenieść takie pozytywne zakończenie w codzienność? - oto wyzwanie między innymi dla nauczyciela prowadzącego lekcję z tego typu lekturą. Jako podsumowanie można zaproponować czytelnikom utworzenie koła samopomocy i pomocy innemu (Co robić, gdybyśmy my znaleźli się na miejscu dzieci z opowiadania? Co można zrobić, gdybyśmy byli kolegami $z$ klasy Mikołaja lub Romka?). Oto propozycje, które można wpisać w koło samopomocy: korzystna może być sama świadomość, że gdy przechodzimy szok kulturowy czy znajdujemy się w kryzysie, ważne jest podtrzymywanie ciepłych relacji z najbliższymi lub, jeśli takich nie mamy, poszukiwanie wsparcia (rozmowy, kontaktu) u innych ludzi; uczenie się języka, by coraz sprawniej funkcjonować w nowym kraju; poznawanie zwyczajów i reguł obowiązujących w danej kulturze; cierpliwość (świadomość, że potrzeba czasu na to, żeby się poczuć lepiej w nowej sytuacji); podtrzymywanie kontaktu z przyjaciółmi z ojczystego kraju; poszukanie profesjonalnego wsparcia u psychologa w razie potrzeby (Grzymała-Moszczyńska, Kownacka 2005; Lipińska 2008). Natomiast w koło pomocy innemu możemy włączyć: zwrócenie uwagi na to, jak ktoś się czuje (empatia); bycie otwartym i serdecznym; ciekawość wobec drugiego (chęć poznania, rozmowy); przerwanie kręgu przemocy i „zmowy milczenia”, jeśli ktoś atakuje obcego w klasie. 


\section{Jak pomóc sobie i innemu?}

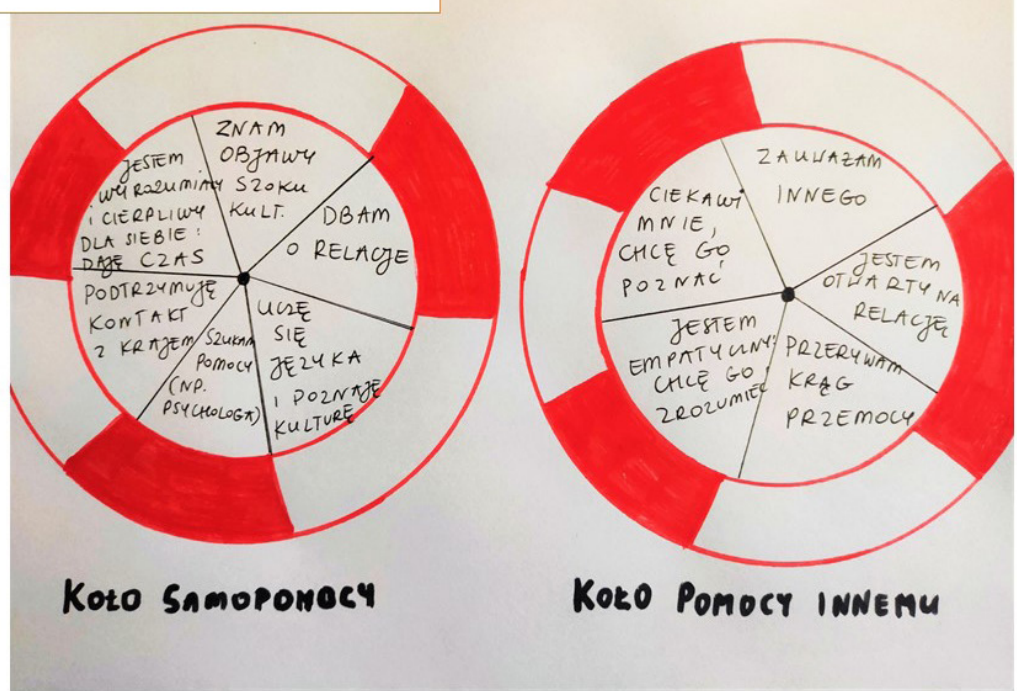

Ilustracja 9. Koło samopomocy i pomocy innemu

Książka Barbary Gawryluk to pozycja obowiązkowa, nie tylko w klasach, gdzie już pojawili się dziecięcy imigranci z Ukrainy lub z innych krajów. Pozwala na wczucie się w ich sytuację i zrozumienie trudności, z którymi się mierzą. Jednocześnie oferuje możliwość autorefleksji nad swoim losem w roli potencjalnego emigranta, a także nad możliwościami i odpowiedzialnością, jaką niesie rola tubylca.

\section{Podsumowanie}

Na temat uchodźców powiedziano w dydaktyce polonistycznej już sporo - przede wszystkim w kontekście dylematów etycznych i powinności nauczyciela oraz humanisty. Pojawiły się również artykuły dokonujące przeglądu literatury poświęconej wyzwaniom globalnego świata oraz prezentujące przykłady praktyki dydaktycznej ${ }^{14}$. Niniejszym tekstem przyłączam się do głosów zaniepokojonych, a czasem słusznie oburzonych polonistów, według których edukacja wielokulturowa nie znajduje odpowiedniego odzwierciedlenia w programach szkolnych. Jednocześnie jestem przekonana o mądrości i autonomii nauczycieli, którzy znają swoich uczniów i chcą podejmować tematy trudne - dotyczące zarówno przeszłości, jak i teraźniejszości. To właśnie do nich kierowana jest niezwykła seria literacka łódzkiego Wydawnictwa Literatura.

\section{Bibliografia:}

Antydyskryminacja. Pakiet edukacyjny, 2005, Centralny Ośrodek Doskonalenia Nauczycieli, Warszawa.

Gawryluk Barbara, 2016, Teraz tu jest nasz dom, Szymanowicz M. (il.), Łódź.

Grzymała-Moszczyńska Halina, Kownacka Ewa, 2005, Szok kulturowy - zło

konieczne?, „Alma Mater”, nr 71. 
Grzymała-Moszczyńska Joanna, 2014, Psychologiczne aspekty powrotów z emigracji-przegląd teoretyczny, „Studia Migracyjne - Przegląd Polonijny”, nr 4.

Lipińska Marzena (red), 2008, Warsztaty kompetencji międzykulturowych - podręcznik dla trenerów, Warszawa.

Nelsen Jane, Lott Lynn, Glenn Stephen, 2020, Pozytywna dyscyplina w klasie, Milik A. (przeł.), Milanówek.

Piątkowska Renata, 2015, Która to Malala?, Szymanowicz M., (il.), Łódź.

Simpson Dorota, 2014, Ekspatrianci wobec szoku kulturowego i odwróconego szoku kulturowego, „Biznes Międzynarodowy w Gospodarce Globalnej”, nr 3.

\section{Źródła internetowe:}

Dearden K., Sánchez Dionis M., Black J., Laczko F., 2020, Calculating “death rates" in the context of migration journeys: Focus on the Central Mediterranean, https://publications.iom.int/system/files/pdf/mortality-rates.pdf (dostęp: 14.05.2020);

International Migration Report 2019, 2019, NowyJork, https://www.un.org/en/ development/desa/population/migration/publications/migrationreport/docs/ InternationalMigration2019 Report.pdf (dostęp: 26.10.2020).

Statystyka migracji w roku 2020, Urząd do Spraw Cudzoziemców, https://migracje.gov.pl/statystyki/zakres/polska/typ/dokumenty/widok/wykresy/rok/2020/ (dostęp: 12.05.2020).

\section{O Autorce:}

Karolina Wawer - literaturoznawczyni, dydaktyk literatury i języka polskiego, adiunkt w Katedrze Polonistycznej Edukacji Nauczycielskiej na Wydziale Polonistyki Uniwersytetu Jagiellońskiego. Autorka książki Drugi plan. Twórczość Wiesława Myśliwskiego w perspektywie postkolonialnej (2018). Interesuje się teorią postkolonialną, sposobami jej stosowania w krytyce literackiej oraz w edukacji polonistycznej, a także cyfrowymi narzędziami polonistyki szkolnej i funkcjonalnym włączaniem ich do warsztatu nauczyciela polonisty. 
